\title{
Effects of contextual cues previously paired with footshock or illness on behavior and pain sensitivity in the rat
}

\author{
GAVAN P. MCNALLY, MARIKA C. GORRISEN, LEE-FAY LOW, and R. FREDERICK WESTBROOK \\ University of New South Wales, Sydney, New South Wales, Australia
}

\begin{abstract}
Rats were used in four experiments to study the effects on behavior and pain sensitivity of exposure to a context previously paired with footshock or injection of the emetic drug lithium chloride (LiCl). Exposure to a context previously paired with footshock or injection of LiCl provoked the speciestypical defense response of freezing (Experiments 1A and 1B). Exposure to a context previously paired with footshock additionally produced hypoalgesia when rats were tested using the tailflick test (Experiment 1A). By contrast, exposure to a context previously paired with injection of LiCl produced hyperalgesia when rats were tested using the tailflick test (Experiment 1B). However, exposure to a context previously paired with injection of $\mathrm{LiCl}$ did provoke hypoalgesia when rats were tested for pain sensitivity using either the hotplate or formalin tests (Experiment 2), which was mediated by the release of endogenous opioid peptides (Experiment 3). These results are discussed with reference to the processes governing associative regulation of defensive behavior and pain control.
\end{abstract}

Exposure to footshock provokes an immediate startle reaction and non-opioid hypoalgesia in rats that is followed by the emergence of the species-typical defense response of freezing and an opioid hypoalgesia (see, e.g., Fanselow, 1980, 1982; Kiernan \& Westbrook, 1993; Kim, Rison, \& Fanselow, 1993; for reviews, see Fanselow, 1991; Fanselow \& Lester, 1988). Associative learning processes enable the context in which footshock has occurred to regulate subsequent defensive behavior and pain sensitivity. Thus, when rats are reexposed to a context previously paired with footshock, they not only display freezing but also hypoalgesia when tested for sensitivity to noxious stimulation (e.g., Fanselow \& Baackes, 1982; Kiernan \& Westbrook, 1993; Kim et al., 1993; for reviews, see Fanselow, 1986; Harris, 1996).

The ability of associative processes to regulate defensive and pain modulatory responses has been subject to two different classes of interpretation. The first class of theory has emphasized the divergence of unconditioned responding to aversive or noxious stimulation and the conditioned responses provoked by environmental stimuli signaling aversive or noxious stimulation. An example of this is the perceptual-defensive-recuperative (PDR) model of fear and pain provided by Bolles and Fanselow (1980), which viewed defensive (e.g., freezing) and hypoalgesic

This research was supported by grants from the Australian Research Council, a Government Employee's Medical Research Fund, and an Australian postgraduate award. We thank R. Richardson, J. A. Harris, and G. Weidemann for helpful comments on the manuscript. G. P. McNally is now at the Mental Health Research Institute, University of Michigan. Correspondence should be addressed to R. F. Westbrook, School of Psychology, University of New South Wales, Sydney 2052, Australia (e-mail: f.westbrook@unsw.edu.au). responses as components of a fear or defensive motivational system that has evolved to afford protection from environmental sources of danger. According to this account, aversive or noxious stimulation and the expectancy of that stimulation have opposing influences on behavior and pain regulation. Specifically, whereas aversive or noxious stimulation arouses a recuperative motivational system promoting behaviors directed toward recovery from tissue damage, the expectancy of aversive stimulation arouses a fear motivational system promoting defensive behaviors and hypoalgesia directed toward escape from the source of aversive stimulation. By contrast, a second class of theories has emphasized the symmetry between behavioral and pain modulatory responses provoked by aversive or noxious stimulation and environmental stimuli signaling aversive or noxious stimulation. Examples of this have been provided by Wagner (1981) and Grau (1987), who have viewed freezing and hypoalgesia as separate but companion responses to the activation of a memorial representation of aversive stimulation. Specifically, Wagner proposed that presentation of an aversive stimulus excites its representation into the center of working memory (or an A1 state of activation), which subsequently decays into the periphery of working memory (or an A2 state of activation) and then into an inactive state. Associative processes enable stimuli present at the time of aversive stimulation to excite a representation of that aversive stimulus into an A2 state of activation. Thus, freezing and opioid hypoalgesia can be viewed as responses to the A2 properties of footshock whose representation has either decayed into that state of activation following its presentation or been excited into that state of activation by associated environmental stimuli (see Grau, 1987, for a review). 
Systemic injection of the illness-inducing drug lithium chloride $(\mathrm{LiCl})$ provokes a stereotypical lying-on-thebelly response and hyperalgesia when rats are tested for pain sensitivity (McNally \& Westbrook, 1998; Wiertelak et al., 1994). By contrast, exposure to a context previously paired with an injection of $\mathrm{LiCl}$ provokes a suppression of grooming and exploratory behaviors as well as the emergence of freezing (e.g., Meachum \& Bernstein, 1992; Parker, Hills, \& Jensen, 1984). It is unknown whether this exposure also regulates pain sensitivity in rats. The experiments reported here studied the behavioral and pain modulatory responses provoked by exposure to a context previously paired with an injection of $\mathrm{LiCl}$. The two classes of theory described above offer different predictions regarding the form of any pain modulatory response provoked by exposure to such a context. Specifically, the PDR model predicts that rats should display conditioned hypoalgesia in a $\mathrm{LiCl}$-associated context because these rats are displaying other indices (e.g., freezing) of the arousal of a defensive motivational system. By contrast, the accounts of Wagner (1981) and Grau (1987) predict that the form of pain modulatory response provoked by the context should be identical to the response tendencies associated with the $\mathrm{A} 2$ properties of $\mathrm{LiCl}$ (e.g., Paletta \& Wagner, 1986). Because the unconditioned pain modulatory response to an injection of $\mathrm{LiCl}$ is hyperalgesia followed by a return to baseline sensitivity (McNally \& Westbrook, 1998), these accounts predict that the context previously paired with an injection of $\mathrm{LiCl}$ should provoke hyperalgesia in rats.

\section{EXPERIMENTS 1A AND 1B}

These two experiments compared the effects on behavior and pain sensitivity of exposure to a distinctive context that had been previously paired with footshock (Experiment 1A) or an injection of $\mathrm{LiCl}$ (Experiment 1B). In the first stage of Experiment 1A (Days 1-7), rats were placed in a distinctive context and subjected to a single footshock. In the second stage of Experiment 1A (Days $8-10$ ), rats were exposed for $30 \mathrm{~min}$ each day to either the conditioning chambers in the absence of shock (Group Same) or to plastic buckets in a second laboratory (Group Different). This extinction manipulation was employed to show that any capacity of the context to modulate pain control was due to its current association with shock. Finally, on test (Day 11), all rats were exposed to the conditioning chambers, and their freezing responses as well as pain sensitivity were measured. In Experiment $1 \mathrm{~B}$, rats were placed in a distinctive context every second day for 14 days and injected with either $\mathrm{LiCl}$ (Group Paired) or saline (Group Unpaired). To equate for exposure to the effects of $\mathrm{LiCl}$, Group Unpaired rats were injected with $\mathrm{LiCl}$ and Group Paired rats with saline on every other day. Following a period of recovery, rats were reexposed to the distinctive context, and their freezing responses as well as pain sensitivity were measured.

\section{Subjects}

The subjects were experimentally naive, adult male Wistar rats weighing between 300 and $500 \mathrm{~g}$ at the start of the experiment. Rats were obtained from the colony of specific-pathogen-free rats maintained by the Combined Universities Laboratory Animal Services (Little Bay, Sydney). Rats were housed in plastic boxes $(60 \mathrm{~cm}$ long $\times 40 \mathrm{~cm}$ wide $\times 20 \mathrm{~cm}$ high) with 8 rats per box. The wire mesh roof of each box held food and water bottles, which were continuously available. The boxes were kept in a colony room maintained under natural lighting. The experiments were conducted between 7:30 a.m. and 6:00 p.m.

\section{Apparatus}

Four standard operant conditioning chambers $(23 \mathrm{~cm}$ long $\times$ $21 \mathrm{~cm}$ wide $\times 20 \mathrm{~cm}$ high) were used as distinctive contexts in Experiment $1 \mathrm{~A}$. The front and rear walls of these chambers, as well as the hinged lid, were constructed of Perspex, and the end walls were made of stainless steel. The floor consisted of stainless steel rods, $2 \mathrm{~mm}$ in diameter, spaced $10 \mathrm{~mm}$ apart, center to center. Water was used to clean the chambers and Vicks VapoRub ${ }^{\mathrm{TM}}$ (Procter \& Gamble, Sydney, Australia) was smeared on paper placed beneath the floor of each chamber to provide a distinctive menthol odor. The four chambers were placed in separate compartments of a wooden cabinet whose floor, ceiling, and walls were painted black. The door of each compartment was kept open and the behavior of each rat was recorded using a camera mounted on the wall facing the open compartments. The camera was connected to a video recorder and monitor located in another room in the laboratory. A constant-current generator allowed delivery of a $0.5-\mathrm{sec} 0.8-\mathrm{mA}$ unscrambled shock to the floor of each chamber. The current available to each floor was adjusted with reference to an in-line milliampere meter. The laboratory was illuminated by eight standard $60-\mathrm{W}$ incandescent lights located in the ceiling, and the ambient temperature was maintained between $21^{\circ}$ and $23^{\circ} \mathrm{C}$. Plastic buckets $(24 \mathrm{~cm}$ in diameter $\times 48 \mathrm{~cm}$ high), located in a different laboratory whose ambient temperature was also maintained between $21^{\circ}$ and $23^{\circ} \mathrm{C}$, were used as a second experimental context. Tailflick testing was conducted using a waterbath (40 cm long $\times 30 \mathrm{~cm}$ wide $\times 35 \mathrm{~cm}$ deep) whose temperature could be maintained at a specific temperature $\left( \pm 0.5^{\circ} \mathrm{C}\right)$ by a Ratek Openbath Thermoregulator (Ratek Instruments, Melbourne, Australia).

\section{Drugs}

Lithium chloride anhydrous (Becton Dickinson, Sydney, Australia) was dissolved in distilled water to yield a concentration of $6.36 \mathrm{~g} / 1(0.15 \mathrm{M})$ and injected in a volume of $20 \mathrm{ml} / \mathrm{kg}$, producing a dose of $127.2 \mathrm{mg} / \mathrm{kg}$ of $\mathrm{LiCl}$. Sterile nonpyrogenic saline $(0.9 \%$ $\mathrm{w} / \mathrm{v}$ ) was used for control injections and injected in a volume of $20 \mathrm{ml} / \mathrm{kg}$. LiCl and saline were injected intraperitoneal (i.p.) using 26-gauge needles.

\section{Procedure}

Rats were handled for $1 \mathrm{~min}$ each day for 5 days prior to the commencement of the experiment.

Experiment 1A: Conditioning. On Days 1-7, rats were transported to the laboratory and placed in the conditioning chambers. Two minutes later rats were removed from the chambers and the distal $4-\mathrm{cm}$ portion of the tail immersed in a $51^{\circ} \mathrm{C}$ waterbath. Latency to remove the tail from the waterbath was recorded by stopwatch. Immediately following tailflick, the tail was wiped with a flannel cloth and rats were returned to the conditioning chambers. Two minutes after tailflick, test rats were given a single footshock. Rats were removed from the chambers $30 \mathrm{sec}$ after footshock and returned to their home cages.

Extinction. On Day 8, rats were randomly allocated to two groups. Rats in Group Same $(n=8)$ were transported to the laboratory and 
placed in the conditioning chambers, whereas rats in Group Different $(n=8)$ were transported to a different laboratory and placed in the plastic buckets. Two minutes later, rats were removed from the chambers or plastic buckets and tested for tailflick latency. Rats were then returned to the conditioning chambers or plastic buckets for a further $28 \mathrm{~min}$. This procedure was repeated on Days 9 and 10 .

Test. On Day 11, all rats were transported to the laboratory and placed in the conditioning chambers. Ten minutes later, rats were removed and tested for tailflick latency. Freezing was defined as the absence of all movement except that related to breathing, including the vibrissae. Freezing was scored from the videotape every 4 th sec during the first $10 \mathrm{~min}$ by an observer blind to each rat's group allocation.

Experiment 1B: Conditioning. On Day 1, rats were transported to the laboratory and placed in the conditioning chambers. Rats were removed 10 min later, injected i.p. with either $\mathrm{LiCl}$ (Group Paired; $n=8$ ) or saline (Group Unpaired; $n=8$ ), and returned to the chambers for $30 \mathrm{~min}$. Eighteen hours later, on Day 2, all rats were removed from their home boxes, injected, and returned to those boxes. Rats in Group Paired were injected with saline whereas rats in Group Unpaired were injected with $\mathrm{LiCl}$. There were seven of these 2-day cycles, so that there were 48-h intervals between each conditioning episode for rats in Group Paired and between each $\mathrm{LiCl}$ exposure for those in Group Unpaired. Rats were allowed $96 \mathrm{~h}$ for recovery between the seventh conditioning trial and test (Days 14 and 19, respectively).

Test. On Day 19, rats were transported to the laboratory and placed in the conditioning chambers for $10 \mathrm{~min}$. Freezing was scored in the manner described previously. The rats were then removed from the conditioning chambers and tested for tailflick latency as described for Experiment 1A. Rats were returned to the conditioning chambers and tested every $5 \mathrm{~min}$ for a further $25 \mathrm{~min}$.

\section{Statistical Analysis}

Data were analyzed by means of planned orthogonal contrasts testing differences between groups. Repeated measures contrasts were tested using a multivariate model (Boik, 1981). The percontrast error rate $(\alpha)$ was controlled at the .05 level using the procedure described by Hays (1972).

\section{Results and Discussion}

Experiment 1A. Mean tailflick latencies from conditioning (Days 1-7), extinction (Days 8-10), and test
(Day 11) are shown in Figure 1. Inspection of this figure indicates that tailflick latencies increased from Day 1 to Day 7. Consistent with the acquisition of a conditioned hypoalgesic response, there was a significant linear increase in tailflick latencies across conditioning days $[F(1,15)=42.9$; critical $F$ value $=4.5]$. A within-group $t$ test confirmed that there was a significant difference between tailflick latencies on Day 1 and Day $7[t(15)=$ 7.2; critical $t$ value $=1.8$ ], confirming the acquisition of an hypoalgesic response across conditioning days. Inspection of the results from tailflick tests conducted during extinction indicates that rats in Group Same were hypoalgesic when tested in the experimental context on Days 8 and 9, but not Day 10, compared with rats in Group Different tested in the plastic buckets whose tailflick latencies did not differ from Day 1 of conditioning. These observations were confirmed by the statistical analysis. There was an overall significant difference in tailflick latencies between rats in Groups Same and Different, averaged across extinction trials $[F(1,14)=15.67$; critical $F$ value $=4.9]$. There was also an overall significant linear decrease in tailflick latencies across days of extinction, averaged across Groups Same and Different $(F=56.39)$. Finally, there was a significant interaction between the contrasts assessing differences between groups and linear trend $(F=70.22)$. Analysis of the nature of this interaction revealed that rats in Group Same were hypoalgesic compared with rats in Group Different on Days 8 $(F=63.42)$ and $9(F=6.71)$ but did not differ from rats in Group Different on Day $10(F<1)$. Finally, inspection of the data from the tailflick test conducted on Day 11 in the experimental context reveals that rats in Group Different were hypoalgesic compared with rats in Group Same. This observation was confirmed by the statistical analysis, which showed that rats in Group Different responded with significantly slower tailflick latencies than rats in Group Same $(F=17.46)$. Thus, rats in Group Same

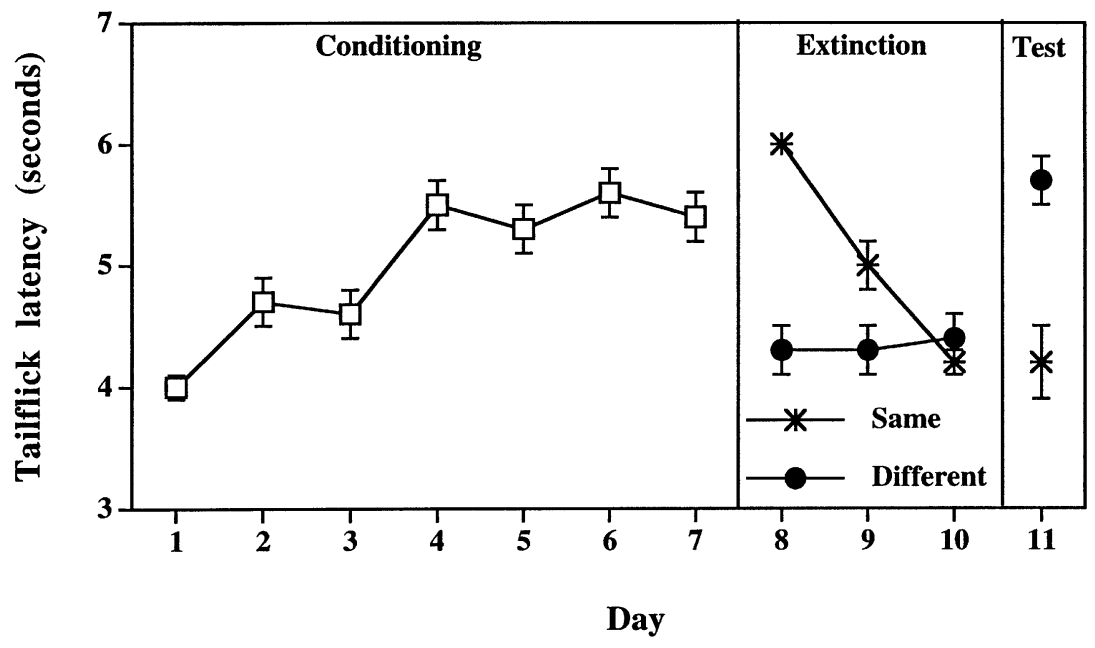

Figure 1. Mean latencies to remove the tail from a $51^{\circ} \mathrm{C}$ waterbath in Experiment $1 \mathrm{~A}$ during conditioning (left panel), extinction (middle panel), and test (right panel). Error bars indicate $S E M$ s. 
were hypoalgesic compared with rats in Group Different on Days 8 and 9, whereas rats in Group Different were hypoalgesic compared with rats in Group Same on Day 11, showing that there was contextually controlled hypoalgesia that depended on the current association between the context and shock.

The mean percentage of occasions spent freezing by rats on Day 11 of Experiment 1A are shown in Figure 2. The statistical analysis confirmed that rats in Group Same spent significantly less time freezing than rats in Group Different $(F=16.5)$, confirming evidence for learned fear in Group Different.

Experiment 1B. The mean percentage of occasions on which rats in Groups Paired and Unpaired froze during the 10 -min exposure to the context on test is shown in the left panel of Figure 3. The statistical analysis showed that rats in Group Paired spent significantly more time freezing than rats in Group Unpaired $[F(1,14)=119.41$; critical $F$ value $=4.6]$.

The mean tailflick latencies for rats in Group Paired and Unpaired on test are shown in the right panel of Figure 3. Statistical analysis confirmed that rats in Group Paired were hyperalgesic compared with those in Group Unpaired since they responded with faster tailflick latencies averaged across the 30 min of test $(F=10.88)$.

Exposed to a context previously paired with footshock, rats displayed the species-typical defense response of freezing and were hypoalgesic when tested for pain sensitivity using the tailflick test (Experiment 1A). There was evidence from this experiment that hypoalgesia was a conditioned response because it was contingent on rats being tested in the presence of contextual cues paired with footshock and was subject to extinction. Specifically, tailflick latencies increased in a linear fashion across days of conditioning. This hypoalgesia was context specific be-

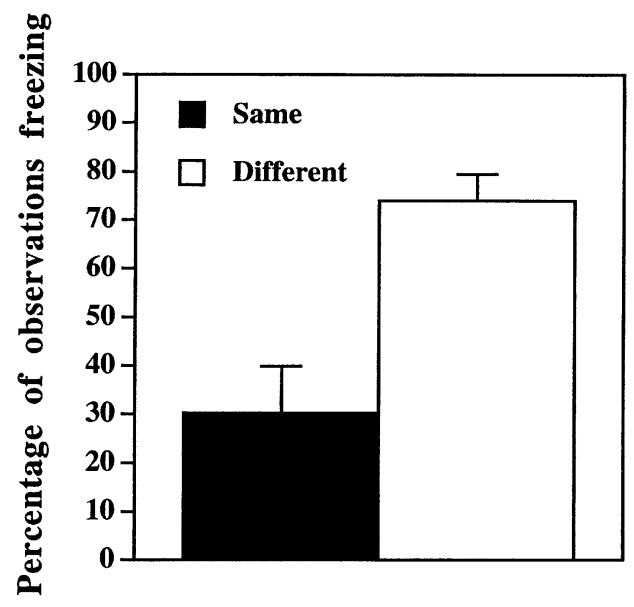

Day 11

Figure 2. Mean percentage of observations spent freezing during reexposure on test (Day 11) in Experiment 1A to the distinctive context previously paired with footshock. Error bars indicate SEMS. cause rats tested in the shock-associated context (Group Same) displayed slower tailflick latencies than rats tested in the second context (Group Different). Moreover, nonreinforced exposures to the shock-associated context reduced this conditioned hypoalgesic response. Thus, the results of Experiment $1 \mathrm{~A}$ confirm previous reports that exposure to a previously shocked context provokes both defensive (e.g., freezing) and hypoalgesic responses in rats (e.g., Fanselow \& Baackes, 1982; Fanselow \& Helmstetter, 1988).

By contrast, exposed to a context previously paired with injection of the emetic drug $\mathrm{LiCl}$, rats displayed the species-typical defense response of freezing but were hyperalgesic when tested for pain sensitivity using the tailflick test (Experiment 1B). There was evidence here that freezing and hyperalgesia were conditioned responses because they were observed in rats tested in the $\mathrm{LiCl}-$ paired context (Group Paired) and not in rats with unpaired exposures to the distinctive context and $\mathrm{LiCl}$. These results not only confirm previous reports that exposure to a distinctive context previously paired with an injection of $\mathrm{LiCl}$ provokes the species-typical defense response of freezing in rats (Meachum \& Bernstein, 1992), but also show for the first time that this exposure also provokes hyperalgesia in rats. Thus, whereas exposure to a context associated with either footshock or illness exerted similar effects on the behavior of rats (i.e., freezing), these exposures produced opposite effects on pain sensitivity (hypoalgesia vs. hyperalgesia) when rats were tested for pain sensitivity using the tailflick test.

\section{EXPERIMENT 2}

This experiment studied whether exposure to a distinctive context previously paired with injection of $\mathrm{LiCl}$ also provokes conditioned hyperalgesia when pain sensitivity is assayed by the hotplate or formalin test. McNally and Westbrook (1998) reported that LiCl produced hyperalgesia when rats were tested for tailflick but failed to detect evidence for hyperalgesia in either the hotplate or the formalin test. It is possible that the differential pain modulatory effects of $\mathrm{LiCl}$ in these three assays were due to LiCl-induced behaviors (e.g., lying-on-the-belly) interfering with the coordinated paw-lifting and paw-licking responses measured in the hot plate and formalin tests. However, it is also possible that these findings represent important differences in the sensitivity of the tailflick, hotplate, and formalin tests to hyperalgesia. Therefore, testing rats following exposure to a $\mathrm{LiCl}$-associated context using the formalin and hotplate tests could produce different effects to testing rats in the tailflick test. In the present experiments, we examined the effects of testing rats using the hotplate, formalin, or tailflick test following exposure to a $\mathrm{LiCl}$-associated context.

This experiment used the same two-group design as that described for Experiment 1B. Thus, rats in the experimental group (Group Paired) were exposed to a distinctive context on seven occasions and injected with $\mathrm{LiCl}$, 

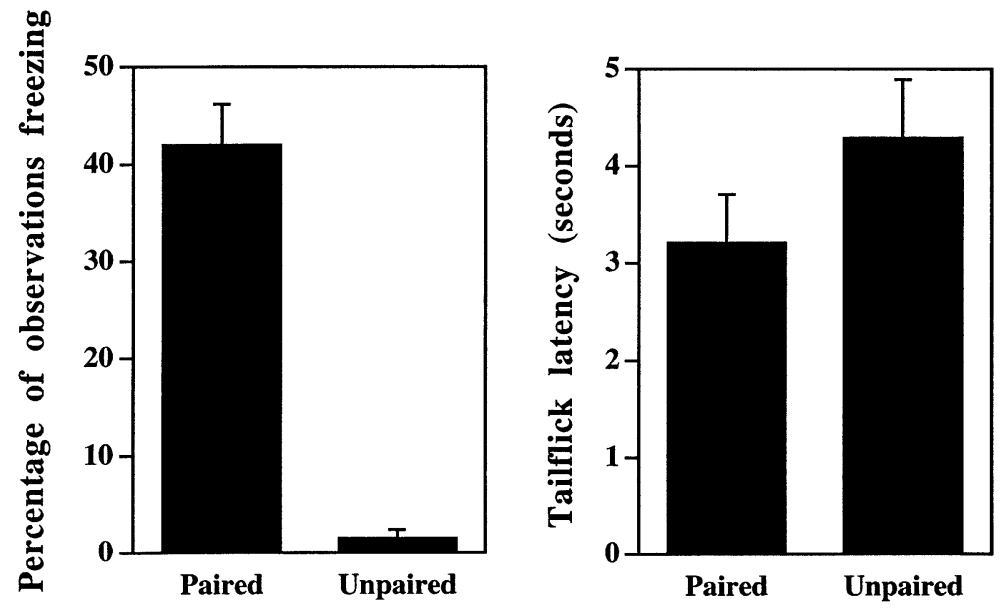

Figure 3. Left panel: Mean percentage of observations spent freezing by rats in Groups Paired and Unpaired during the 10-min exposure to the distinctive context on test in Experiment 1B. Right panel: Mean latencies to remove the tail from a $51^{\circ} \mathrm{C}$ waterbath during exposure to the distinctive context on test in Experiment 1B. Rats in Group Paired had previously been injected with $127.2 \mathrm{mg} / \mathrm{kg}$ of LiCl seven times in the distinctive context, whereas rats in Group Unpaired had been injected seven times with saline. Error bars indicate $S E M$ s.

whereas rats in the control group (Group Unpaired) were exposed to the distinctive context and injected with saline. Following conditioning, rats were reexposed to this context and their behavior was observed. Rats were then tested for pain sensitivity in the distinctive context using the hotplate, formalin, or tailflick tests. For hotplate testing, rats were exposed to the $52^{\circ} \mathrm{C}$ heated floor of the hotplate apparatus in the distinctive context; for formalin testing, rats were exposed to the nonheated floor of that apparatus in the distinctive context and injected with dilute formalin into the right hind-paw; for tailflick testing, rats were exposed to a nonheated floor in the distinctive context and tested for tailflick latency. We did not study the effects of exposure to a context previously paired with footshock in this experiment because there is considerable evidence that exposure to a context previously paired with aversive or noxious stimulation produces analgesia in the formalin test (e.g., Fanselow \& Baackes, 1982) and the hotplate test (e.g., Harris \& Westbrook, 1994).

\section{Method}

\section{Subjects and Apparatus}

Subjects were 36 experimentally naive male Wistar rats weighing between 300 and $400 \mathrm{~g}$ at the start of the experiment. Rats were obtained from the same source and maintained under the same conditions as described previously. Two Plexiglas chambers (24-cm diameter $\times 48$-cm height) with $1-\mathrm{mm}$ thick copper floors fixed $12 \mathrm{~cm}$ above the base of the chamber were used as conditioning contexts. Each chamber sat in a bath of water $(40 \mathrm{~cm}$ long $\times 30 \mathrm{~cm}$ wide $\times$ $35 \mathrm{~cm}$ deep), and the portion of the chamber below the copper floor was perforated with holes $3 \mathrm{~cm}$ in diameter to permit circulation of water beneath the floor. The temperature of each waterbath was maintained by a Ratek Open-Bath thermoregulator (Ratek Instruments, Melbourne, Australia). During conditioning, the waterbaths were maintained at $23^{\circ} \mathrm{C}$. These chambers were located in a laboratory whose ambient temperature was maintained between $21^{\circ}$ and $23^{\circ} \mathrm{C}$. Acetic acid $(0.5 \%)$ was used to clean the copper floor of the Plexiglas chambers upon removal of each rat. The laboratory was illuminated by four ceiling-mounted $150-\mathrm{W}$ fluorescent lights.

\section{Drugs}

$\mathrm{LiCl}$ and saline were prepared and injected as described in Experiment 1B. A saturated formaldehyde solution $(37.5 \%-40 \%)$ was diluted in sterile nonpyrogenic saline $(0.9 \% \mathrm{w} / \mathrm{v})$ to obtain a concentration of $1 \%$ formalin and injected subcutaneously (s.c.) into the plantar surface of the right hind-paw in a volume of $50 \mu \mathrm{l}$ using 29 -gauge needles. A $1 \%$ formalin solution was selected in order to maximize detection of hyperalgesia since previous work from this laboratory has shown that this concentration produces submaximal responding in the present strain of rats (Abbott, Franklin, \& Westbrook, 1995; McNally \& Westbrook, 1998).

\section{Procedure}

Rats were handled for $1 \mathrm{~min}$ each day for 5 days prior to the commencement of the experiment.

Conditioning. On Day 1, rats were transported to the laboratory. Each rat was placed into one of the Plexiglas chambers, removed 10 min later, injected i.p. with either LiCl (Group Paired; $n=18$ ) or saline (Group Unpaired; $n=18$ ) and placed in the other Plexiglas chamber for $30 \mathrm{~min}$. Eighteen hours later, on Day 2, all rats were removed from their home boxes, injected, and returned to those boxes. Rats in Group Paired were injected with saline, whereas rats in Group Unpaired were injected with $\mathrm{LiCl}$. There were seven of these 2-day cycles, so there were 48-h intervals between each conditioning episode for rats in Group Paired and between each $\mathrm{LiCl}$ exposure for those in Group Unpaired. Rats were allowed $96 \mathrm{~h}$ for recovery between the seventh conditioning trial and test (Days 14 and 19 , respectively).

Test. On Day 19, rats were transported to the laboratory and placed in the $23^{\circ} \mathrm{C}$ Plexiglas chamber for $10 \mathrm{~min}$. Freezing was scored during this period by an observer unaware of each rat's group 
allocation using a time-sampling procedure in which each rat was observed every 4 th sec. Rats were tested using the formalin, hotplate, or tailflick test 5 min later.

Formalin testing. Rats ( $n=6$ per group) were removed from the Plexiglas chamber and injected with $50 \mu 1$ of $1 \%$ formalin into the plantar surface of the right hind-paw. During injection, rats were loosely wrapped in a flannel cloth, the right hind-paw marked, and the needle inserted between the distal tips of the two basal tori before being advanced $2-3 \mathrm{~mm}$ proximally. Immediately following formalin injection, rats were placed into the other chamber, whose floor was maintained at $23^{\circ} \mathrm{C}$, and the amount of time spent lifting or licking/biting the injected paw was recorded for $30 \mathrm{~min}$.

Hotplate testing. Rats ( $n=6$ per group) were removed from the $23^{\circ} \mathrm{C}$ chamber, placed into the other chamber whose floor was heated (the water surrounding the floor of the test chamber was maintained at $52^{\circ} \mathrm{C}\left[0.5^{\circ} \mathrm{C}\right]$, and the latency to first paw-lick (front or back, whichever occurred first) by push buttons connected to a computer. Rats were removed from the chamber immediately following first paw-lick and returned to their home boxes.

Tailflick testing. Rats ( $n=6$ per group) were removed from the chamber and tested for tailflick latency as described in Experiment $1 \mathrm{~B}$. Immediately following tailflick rats were returned to the chamber. This procedure was repeated a further five times at 5-min intervals.

\section{Statistical Analysis}

The data from test were analyzed by means of planned orthogonal contrasts assessing differences between groups. The per-contrast error rate $(a)$ was controlled at the .05 level using the procedures described in Experiment 1A and 1B.

\section{Results and Discussion}

The mean percentage of occasions on which rats froze during the 10-min test period is shown in Figure 4. Inspection of the figure indicates that rats in Group Paired had learned to fear the LiCl-associated chamber since they froze significantly more than rats in Group Unpaired $[F(1,34)=36.9$; critical $F$ value $=4.1]$.

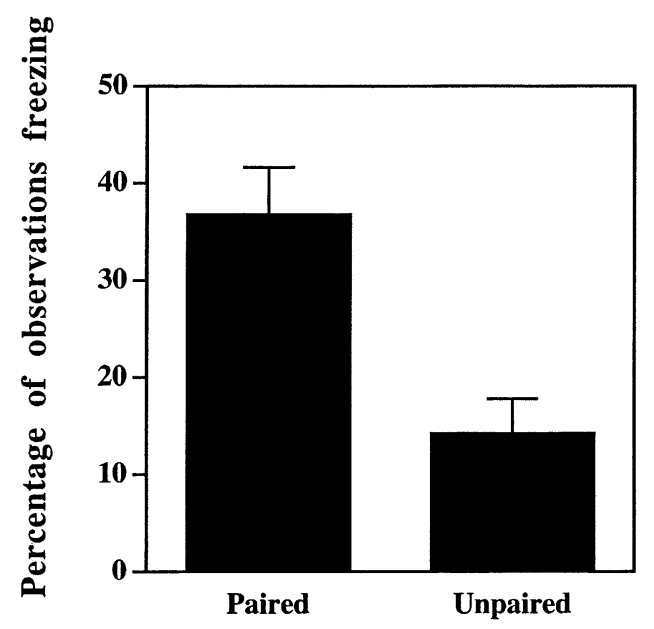

Figure 4. Mean percentage of observations spent freezing by rats in Groups Paired and Unpaired during the 10-min observation period on test in Experiment 2. Rats in group Paired had previously been injected seven times with $127.2 \mathrm{mg} / \mathrm{kg}$ of $\mathrm{LiCl}$ in the distinctive context, whereas rats in Group Unpaired had been injected seven times with saline. Error bars indicate $S E M$ s.
The mean latencies with which rats licked their paws following exposure to the $52^{\circ} \mathrm{C}$ floor are shown in the left panel of Figure 5 . The statistical analysis revealed that rats in Group Paired exhibited conditioned hypoalgesia, taking significantly longer to lick their paws than rats in Group Unpaired $[F(1,10)=17.2$; critical $F$ value $=4.9]$. The mean percentage of time spent responding to the formalin-injected paw is shown in the middle panel of Figure 5. The statistical analysis showed that rats in Group Paired again exhibited conditioned hypoalgesia, spending significantly less time responding to the formalin-injected paw than did rats in Group Unpaired $(F=5.1)$. The mean latencies from the tailflick tests are shown in the right panel of Figure 5. The statistical analysis confirmed the evidence for conditioned hyperalgesia found in Experiment 1B: Rats in Group Paired responded with significantly faster tailflick latencies than did rats in Group Unpaired across the 30-min test period $(F=6.7)$.

The results of this experiment confirm that exposure to a context previously paired with injection of $\mathrm{LiCl}$ provokes the species-typical defense response of freezing in rats, as well hyperalgesia when rats are tested using the tailflick test. Furthermore, this experiment shows that, in contrast to the results observed using the tailflick test, this exposure elicits conditioned hypoalgesia when rats are tested in the hotplate and formalin tests relative to the unpaired control group. This influence of test type on the form of conditioned pain modulatory response provoked by exposure to a $\mathrm{LiCl}$-associated context is consistent with the acute effects of $\mathrm{LiCl}$ in these assays whereby injection of $\mathrm{LiCl}$ produces hyperalgesia in the tailflick test but not in either the formalin or hotplate test (McNally \& Westbrook, 1998).

\section{EXPERIMENT 3}

This experiment studied the involvement of endogenous opioid peptides in the associatively mediated alterations in nociceptive sensitivity produced by exposing rats to a context previously paired with an injection of $\mathrm{LiCl}$. Specifically, rats were injected with the competitive opioid receptor antagonist naloxone prior to exposure to the distinctive context on test. There is substantial evidence that the activity of endogenous opioid peptides plays a critical role in the production of conditioned hypoalgesic responses (see Harris, 1996, for review), and naloxone reversibility of conditioned hypoalgesia is a standard criterion for inferring the involvement of endogenous opioid peptides.

The procedure used in the present experiment employed Groups Paired and Unpaired as in Experiment 2 but differed in four ways from that used in Experiment 2. First, rats were tested initially using the formalin test and $96 \mathrm{~h}$ later using the tailflick test. The hotplate test was not used in this experiment because there is evidence that conditioned hypoalgesia in this assay is not prevented by an injection of naloxone (e.g., Foo \& Westbrook, 1994). Second, rats were tested for conditioned hypoalgesia 

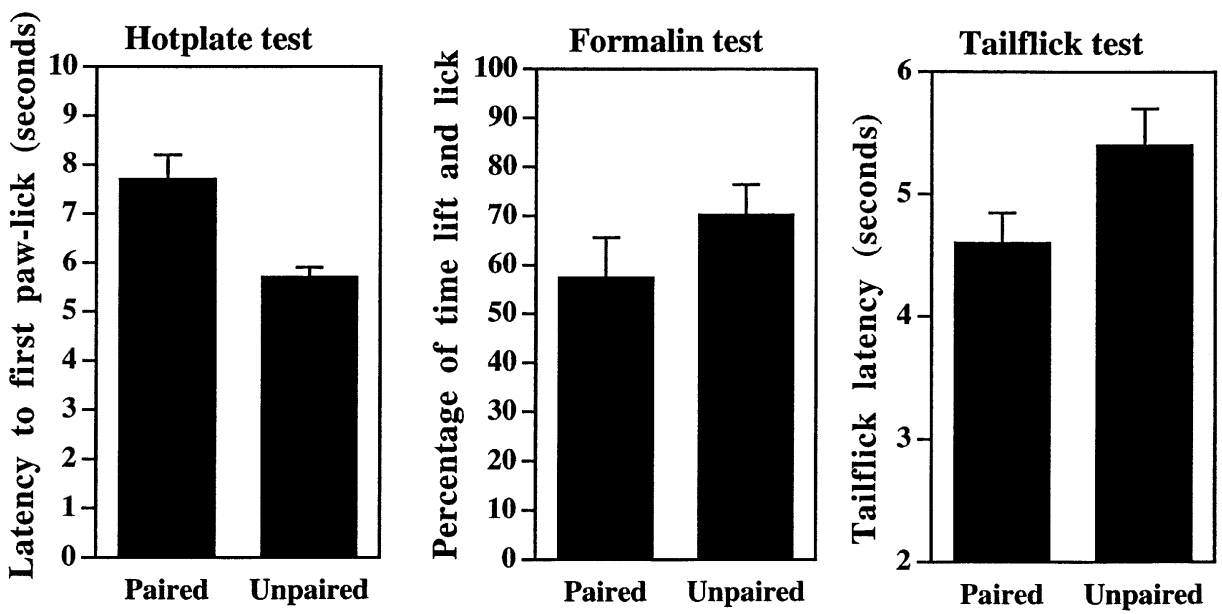

Figure 5. Left panel: Mean latencies to first paw-lick for rats in Groups Paired and Unpaired following exposure to the $52^{\circ} \mathrm{C}$ floor on test in Experiment 2. Middle panel: Mean percentage of time spent responding to the formalin-injected paw for rats in Groups Paired and Unpaired on test in Experiment 2. Right panel: Mean latencies to remove the tail from a $51^{\circ} \mathrm{C}$ waterbath on test in Experiment 2. Error bars indicate $S E M$ s.

30-40 min after injection of dilute formalin into a hindpaw. Previous work from this laboratory has demonstrated that the behavioral response to formalin is stable during this period (Abbott et al., 1995) and is highly sensitive to manipulations that produce hypoalgesia (Harris $\&$ Westbrook, 1994). Third, a concentration of $1.5 \%$ formalin was used because pilot studies indicated that testing with this higher concentration of formalin produces maximal evidence for conditioned hypoalgesia. Finally, freezing was scored during the seventh conditioning trial and not during the pain test to reduce the effects of any extinction that might have occurred by interpolating the 10 -min test for freezing between context reexposure and formalin test. Each of these procedural changes was designed to maximize the evidence for associatively mediated alterations in pain sensitivity.

\section{Method}

\section{Subjects and Apparatus}

Subjects were 32 experimentally naive adult male Wistar rats obtained from the same source and maintained under the same conditions described previously. The apparatus was that described in Experiment $1 \mathrm{~A}$. Acetic acid $(0.5 \%)$ was used to clean the floor of each chamber upon removal of a rat. In addition, a mirror was placed at $45^{\circ}$ beneath the floor of each chamber.

\section{Drugs}

$\mathrm{LiCl}$ and saline were prepared and injected in the manner described for Experiment 1. Naloxone hydrochloride (Sigma Chemical Co., Sydney) was dissolved in sterile nonpyrogenic saline $(0.9 \%$ $\mathrm{w} / \mathrm{v}$ ) to obtain a concentration of $2.5 \mathrm{mg} / \mathrm{kg}$ and injected s.c. in the dorsal neck region in a volume of $1 \mathrm{ml} / \mathrm{kg}$. Nonpyrogenic saline $(0.9 \% \mathrm{w} / \mathrm{v})$ was used for control injections and injected in a volume of $1 \mathrm{ml} / \mathrm{kg}$. A saturated formaldehyde solution was prepared as described previously to obtain a concentration of $1.5 \%$ formalin, and injected as described in Experiment 2.

\section{Procedure}

Rats were handled each day for 1 min for 5 days prior to the commencement of this experiment.

Conditioning. The procedure for conditioning was the same as that described for Experiment 1B. Forty-eight hours after formalin test, on Day 21, rats received an additional conditioning trial to minimize the effects of any extinction that might have accrued from exposure to the experimental context during formalin test. This trial was identical to the conditioning trials described for Experiment $1 \mathrm{~B}$.

Test. On Day 19, rats were transported to the laboratory. On arrival rats were injected with formalin in the manner described for Experiment 2. Naloxone or saline was injected $10 \mathrm{~min}$ later. Twenty minutes later rats were placed in the chambers and the amount of time spent lifting or biting/licking the formalin-injected paw was recorded for $10 \mathrm{~min}$. On Day 23, $48 \mathrm{~h}$ after the eighth conditioning trial, rats were tested for tailflick latency. This test employed a crossover design in which rats previously tested with naloxone were now tested with saline, whereas rats previously tested with saline were now tested with naloxone. On Day 23, rats were injected with either naloxone or saline and placed in the experimental chambers 20 min later. Rats were removed from the chambers and tested 5 min later for tailflick latency in the manner described for Experiment 1 . Tailflick testing was repeated a further five times at 5 -min intervals.

Behavioral ratings. Freezing during the initial 10-min exposure to the chambers on the seventh conditioning trial (Day 13) was scored every 4th sec by an observer blind to each rat's group allocation.

\section{Statistical Analysis}

The data were analyzed and the per contrast error rate $(\alpha)$ controlled at the .05 level using the procedures described in Experiment 1.

\section{Results and Discussion}

One rat in Group Unpaired developed an infection and was excluded from the experiment and 1 rat from Group Paired was excluded because of difficulties with formalin injection. The mean percentage of occasions on which 

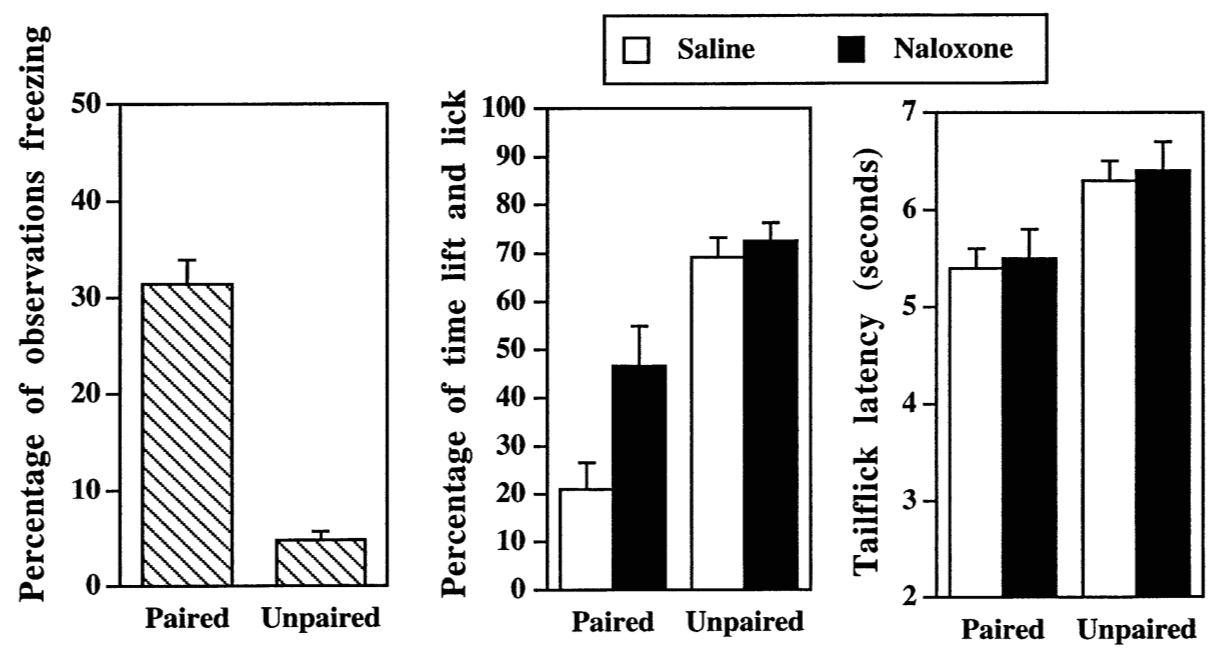

Figure 6. Left panel: Mean percentage of observations spent freezing by rats in Groups Paired and Unpaired during the 10-min observation period, prior to injection of $\mathrm{LiCl}$ or saline, on the seventh conditioning trial (Day 13) in Experiment 3. Middle panel: Mean percentage of observations spent responding to the formalin-injected paw for rats in Groups Paired and Unpaired on test (Day 19) in Experiment 3. Right panel: Mean latencies to remove the tail from a $51^{\circ} \mathrm{C}$ waterbath on test (Day 23) in Experiment 3. Error bars indicate SEMs.

rats in each of the groups froze on the seventh conditioning trial on Day 13 is shown in the left panel of Figure 6. The statistical analysis showed that rats in Group Paired had learned to fear the LiCl-associated context since they froze significantly more than rats in Group Unpaired $[F(1,29)=95.8$; critical $F$ value $=4.2]$.

The mean percentage of time spent responding to the formalin-injected paw is shown in the middle panel of Figure 6. Inspection of the panel indicates that rats in Group Paired were hypoalgesic because they spent less time responding to the formalin-injected paw than rats in Group Unpaired, and that systemic injection of naloxone attenuated this conditioned hypoalgesia. These observations were confirmed by the statistical analysis. There was evidence for conditioned hypoalgesia since rats in Group Paired spent significantly less time responding to the formalin-injected paw than rats in Group Unpaired $[F(1,26)=39.8 ;$ critical $F$ value $=4.23]$. There was also a main effect for naloxone in the conditioning group $(F=$ 9.6), but not in the control group $(F<1)$, consistent with a role for opioid involvement in this conditioned hypoalgesia. However, this conclusion needs to be qualified by the fact that the interaction term approximated but did not reach the conventional level of significance $[F(1,26)=$ 3.7 ; critical $F$ value $=4.23$.

The mean latencies with which rats flicked their tails out of the hotwater bath are shown in the right panel of Figure 6. Inspection of the panel indicates that rats in Group Paired were hyperalgesic because they responded with significantly faster tailflick latencies than rats in Group Unpaired, and that naloxone failed to influence this conditioned hyperalgesic response. The statistical analysis confirmed that rats in Group Paired were hyper- algesic relative to rats in Group Unpaired, averaged across injection of naloxone or saline $[F(1,27)=21.9]$. There was no evidence for a main effect of naloxone in either the conditioning $(F<1)$ or the control $(F<1)$ group, and the interaction term was also nonsignificant $(F<1)$. Thus, systemic injection of naloxone failed to attenuate the conditioned hyperalgesia provoked by exposure to the context previously paired with an injection of $\mathrm{LiCl}$.

The results of this experiment confirm that exposure to a context previously paired with an injection of $\mathrm{LiCl}$ provokes freezing and either hypoalgesia or hyperalgesia in the formalin and tailflick tests, respectively. Moreover, these results show that the conditioned hypoalgesic but not hyperalgesic response is mediated, at least in part, by the release of endogenous opioid peptides because it was attenuated by systemic injection of the opioid receptor antagonist naloxone.

\section{GENERAL DISCUSSION}

The experiments reported here studied the effects on behavior and pain sensitivity of exposure to a context previously paired with either footshock or injection of $\mathrm{LiCl}$. Exposure to a context previously paired with footshock elicited defense responses of freezing and hypoalgesia when rats were tested for pain sensitivity using the tailflick test (Experiment 1A). By contrast, exposure to a context previously paired with injection of the illnessinducing drug $\mathrm{LiCl}$ elicited the defense response of freezing and hyperalgesia when rats were tested for pain sensitivity using the tailflick test (Experiment 1B). However, exposure to a $\mathrm{LiCl}$-associated context did provoke hypoalgesia when rats were tested using either the formalin or 
the hotplate test (Experiment 2). Moreover, the conditioned hypoalgesia observed in the formalin test depended critically on the release of endogenous opioid peptides because it could be prevented by systemic injection of the opiate receptor antagonist naloxone (Experiment 3).

The alterations in pain sensitivity observed in rats exposed to the LiCl- or shock-associated context could be linked to the unconditioned pain modulatory effects of shock and $\mathrm{LiCl}$ (see, e.g., Grau, 1987; Wagner, 1981). Specifically, the hypoalgesia observed upon reexposure to the shock-associated context could have emerged from an unconditioned hypoalgesic response to shock, whereas the hyperalgesia and hypoalgesia observed upon reexposure to the $\mathrm{LiCl}$-associated context could have emerged from the dual unconditioned hypoalgesic and hyperalgesic response to illness. Consistent with these possibilities, there is evidence for an unconditioned hypoalgesic response to shock (e.g., Terman, Shavit, Lewis, Cannon, \& Liebeskind, 1984; Watkins \& Mayer, 1982), but this response is typically elicited by shock of greater intensity and duration than that used here (e.g., Fanselow, Landeira-Fernandez, DeCola, \& Kim, 1994). Although hyperalgesia is the predominant pain modulatory response to illness (Watkins, Maier, \& Goehler, 1995), $\mathrm{LiCl}$ can also produce hypoalgesia in rats. For example, pharmacological blockade of the hyperalgesia produced by illness does not return pain sensitivity to baseline but instead reveals a transient hypoalgesic response (see Maier \& Watkins, 1998, for review). Hyperalgesia is not readily detected in either the formalin or the hotplate tests across a range of stimulus intensities and $\mathrm{LiCl}$ doses (McNally \& Westbrook, 1998). Instead, high doses of $\mathrm{LiCl}$, such as those used here, appear to produce hypoalgesia in the hotplate (Yirmiya, Lieblich, Liebeskind, \& Garcia, 1988) and formalin tests (McNally \& Westbrook, 1998). Thus, the pain modulatory changes produced by exposure to the shock- and $\mathrm{LiCl}$-associated context could have emerged from the unconditioned pain modulatory responses to shock and illness, which simply transferred to the distinctive context (e.g., Terman et al., 1984; Watkins \& Mayer, 1982), or they could have been responses to the $\mathrm{A} 2$ activation of footshock and $\mathrm{LiCl}$ whose representations were excited into that state of activation by the associated context (e.g., Grau, 1987; Wagner, 1981).

However, an important limitation of these accounts, as applied to the present data, is their inability to explain the occurrence of freezing in rats exposed to the LiClassociated context. Whereas the pain modulatory responses observed following exposure to a $\mathrm{LiCl}$-associated context were similar to the unconditioned effects of $\mathrm{LiCl}$, the behavioral responses provoked by this exposure were not (see also Meachum \& Bernstein, 1992). The predominant responses observed within $60 \mathrm{~min}$ of an injection of $\mathrm{LiCl}$ are a stereotypical lying-on-the-belly response and somnolesence but, importantly, not freezing (see, e.g., Meachum \& Bernstein, 1990). It remains to be determined whether freezing is observed at intervals greater than 60 min following injection of $\mathrm{LiCl}$, but we consider this possibility unlikely. For example, we have studied rats injected with illness-inducing agents (e.g., $\mathrm{LiCl}$ or the bacterial endotoxin, Lipolysaccharide) up to $4 \mathrm{~h}$ following injection and failed to observe freezing (McNally \& Westbrook, unpublished observations).

Alternatively, the present results could be interpreted with reference to the PDR model of fear and pain proposed by Bolles and Fanselow (1980). The co-occurrence of hypoalgesia and freezing in rats exposed to contextual cues previously paired with footshock is consistent with this model. Specifically, freezing and hypoalgesia are viewed as responses to the conditioned arousal of a fear or defensive motivational system by the context previously paired with footshock. The illness induced by an injection of $\mathrm{LiCl}$ could be treated in the same manner as footshock by this model because both can be viewed as arousing recuperative behaviors directed toward recovery (see, e.g., Bolles \& Fanselow, 1980; Maier \& Watkins, 1998). Indeed, Bolles and Fanselow noted the clear parallel between the functional significance of pain and illness. It follows, therefore, that pairing the effects of $\mathrm{LiCl}$ with a distinctive context could function in the same manner as pairings of shock with a distinctive context, imbuing the contextual cues with the ability to arouse a fear or defensive motivational system and thus releasing freezing and hypoalgesia. Nonetheless, it is difficult to reconcile this possibility with the differential effects in the tailflick test produced by exposure to the LiCl- and shock-associated contexts. Specifically, whereas both freezing and hypoalgesia were observed upon reexposure to the shock-associated context, freezing and hyperalgesia were observed upon reexposure to the $\mathrm{LiCl}$-associated context when rats were tested for pain sensitivity using the tailflick test. Although the results from the hotplate and formalin tests (Experiments 2 and 3) are consistent with the PDR model, the results from the tailflick test (Experiment 1B) are not. It could be argued that decreased tailflick latencies are not indicative of increased pain sensitivity (see, e.g., Illich, King, \& Grau, 1995; King, Joynes, Meagher, \& Grau, 1996; but see McNally, 1999), and therefore are not relevant to the PDR model. Further experiments are required to address this issue and to determine whether exposure to the $\mathrm{LiCl}$-associated context provokes additional behavioral and autonomic changes consistent with conditioned arousal of a fear or defensive motivational system.

Finally, the results of the present experiments add to the growing body of evidence showing that exposure to a distinctive context followed by an injection of $\mathrm{LiCl}$ establishes a context $-\mathrm{LiCl}$ association in rats. Previously this association has been revealed by reexposing rats to the distinctive context and observing their behavior (e.g., Meachum \& Bernstein, 1992; Parker et al., 1984) or by studying the ability of this learning to block subsequent flavor-illness learning in that context (e.g., Best, Brown, \& Sowell, 1984; Krane, 1980; Rudy, Iwens, \& Best, 1977; Symonds \& Hall, 1997; Westbrook \& Brookes, 1988; Willner, 1978). The present experiments show that 
this learning also reliably alters pain sensitivity in rats. These associatively mediated alterations in pain sensitivity could provide useful measures in the study of the neural bases of context-illness learning (e.g., Aguado, Hall, Harrington, \& Symonds, 1998).

\section{REFERENCES}

Aвbott, F. V., Franklin, K. B. J., \& Westbrook, R. F. (1995).The formalin test: Scoring properties of the first and second phases of the pain response in rats. Pain, 60, 91-102.

Aguado, L., Hall, G., Harrington, N., \& Symonds, M. (1998). Illness-induced context aversion learning in rats with lesions of the dorsal hippocampus. Behavioral Neuroscience, 112, 1142-1151.

Best, M. R., Brown, E. R., \& Sowell, M. K. (1984). Taste-mediated potentiation of non-ingestional cues in rats. Learning \& Motivation, 15, 244-258.

BoIK, R. J. (1981). A priori tests in repeated measures designs: Effects of non-sphericity. Psychometrika, 46, 241-255.

Bolles, R. C., \& Fanselow, M. S. (1980). A perceptual-defensiverecuperative model of fear and pain. Behavioral \& Brain Sciences, $\mathbf{3}$, 291-323.

FANSELOW, M. S. (1980). Conditioned and unconditioned components of post-shock freezing. Pavlovian Journal of Biological Sciences, 15 177-182.

FANSELOW, M. S. (1982). The postshock activity burst. Animal Learning \& Behavior, 10, 448-454.

FANSELOW, M. S. (1986). Conditioned fear-induced opiate analgesia. A competing motivational state theory of stress-analgesia. In D. D. Kelly (Ed.), Stress-induced analgesia (Annals of the New York Academy of Sciences, Vol. 467, pp. 40-54). New York: New York Academy of Sciences.

FANSELOw, M. S. (1991). The midbrain periaqueductal gray as a coordinator of action in response to fear and anxiety. In A. Despaulis \& R. Bandler (Eds.), The midbrain periaqueductal gray matter (pp. 151173). New York: Plenum.

FAnselow, M. S., \& BAACKES, M. P. (1982). Conditioned fear-induced opiate analgesia in the formalin test: Evidence for two aversive motivational systems. Learning \& Motivation, 13, 200-221.

Fanselow, M. S., \& Helmstetter, F. J. (1988). Conditional analgesia, defensive freezing, and benzodiazepines. Behavioral Neuroscience, 102, 233-243

Fanselow, M. S., Landeira-Fernandez, J., DeCola, J. P., \& Kim, J. J. (1994). The immediate-shock deficit and postshock analgesia: Implications for the relationship between the analgesic CR and UR. Animal Learning \& Behavior, 22, 72-76.

FAnselow, M. S., \& Lester, L. S. (1988). A functionalistic behavioristic approach to aversively-motivated behavior: Predatory imminence as a determinant of the topography of defensive behavior. In R. C. Bolles \& M. D. Denny (Eds.), Evolution and learning (pp. 185212). Hillsdale, NJ: Erlbaum.

Foo, H., \& Westbrook, R. F. (1994). The form of conditioned hypoalgesic response resulting from preexposure to a heat stressor depends on the pain test used. Psychobiology, 22, 173-179.

GraU, J. W. (1987). The central representation of an aversive event maintains the opioid and non-opioid forms of analgesia. Behavioral Neuroscience, 98, 278-292

Harris, J. A. (1996). Descending antinociceptive systems in the brainstem: Their role in the animal's defensive system. Journal of Physiology, 90, 15-25.

Harris, J. A., \& Westbrook, R. F. (1994). Effects of midazolam and naloxone in rats tested for sensitivity/reactivity to formalin pain in a familiar, novel, or aversively conditioned environment. Psychopharmacology, 92, 491-504.

Hays, W. L. (1972). Statistics for the social sciences. New York: Holt, Rinehart \& Winston.

Illich, P. W., KING, T. E., \& GraU, J. W. (1995). Impact of shock on pain reactivity: Whether hypo- or hyperalgesia is observed depends on how pain reactivity is tested. Journal of Experimental Psychology: Animal Behavior Processes, 21, 331-347.
Kiernan, M. J., \& Westbrook, R. F. (1993). Effects of exposure to a to-be-shocked environment upon the rat's freezing response: Evidence for facilitation, latent inhibition, and perceptual learning. Quarterly Journal of Experimental Psychology, 46B, 271-288.

Kim, J. J., Rison, R. A., \& FAnselow, M. S. (1993). Effects of amygdala, hippocampus, and periaqueductal gray lesions on short- and longterm contextual fear. Behavioral Neuroscience, 107, 1093-1098.

King, T. E., Joynes, R.L., Meagher, M. W., \& GraU, J. W. (1996). Impact of shock on pain reactivity: II. Evidence for enhanced pain. Journal of Experimental Psychology: Animal Behavior Processes, 22, 265-278.

Krane, R. V. (1980). Toxiphobia conditioning with exteroceptive cues. Animal Learning \& Behavior, 8, 513-523.

MAIER, S. F., \& WATKINS, L. R. (1998). Cytokines for psychologists: Implications of bidirectional immune-to-brain communication for understanding behavior, mood, and cognition. Psychological Review, 105, 83-107.

MCNALLY, G. P. (1999). Pain facilitatory circuits in the mammalian central nervous system: Their behavioral significance and role in morphine hypoalgesic tolerance. Neuroscience \& Biobehavioral Reviews, 23, 1059-1078.

McNally, G. P., \& Westbrook, R. F. (1998). Test type influences the expression of lithium chloride-induced hyperalgesia. Pharmacology Biochemistry \& Behavior, 61, 385-394.

Meachum, C. L., \& Bernstein, I. L. (1990). Conditioned responses to a taste conditioned stimulus paired with lithium chloride administration. Behavioral Neuroscience, 104, 711-715.

Meachum, C. L., \& Bernstein, I. L. (1992). Behavioral conditioned responses to contextual and odor stimuli paired with $\mathrm{LiCl}$ administration. Physiology \& Behavior, 52, 895-899.

Paletta, M. S., \& Wagner, A. R. (1986). Development of contextspecific tolerance to morphine: Support for a dual process model. Behavioral Neuroscience, 100, 611-623.

PARKer, L. A., Hills, K., \& Jensen, K. (1984). Behavioral CRs elicited by a lithium- or an amphetamine-paired contextual chamber. Animal Learning \& Behavior, 12, 307-315.

Rudy, J. W., IwENS, J., \& Best, P. J. (1977). Pairing novel exteroceptive cues and illness reduces illness-induced taste aversions. Journal of Experimental Psychology: Animal Behavior \& Processes, 3, 14-25.

Symonds, M., \& Hall, G. (1997). Contextual conditioning with lithiuminduced nausea as the US: Evidence from a blocking procedure. Learning \& Motivation, 28, 200-215.

Terman, G. W., Shavit, Y., Lewis, J. W., Cannon, J. T., \& Liebeskind, J. C. (1984). Intrinsic mechanisms of pain inhibition. Science, 226, 1270-1277.

WAGNER, A. R. (1981). SOP: A model of automatic memory processing in animals. In N. E. Spear \& R. R. Miller (Eds.), Information processing in animals: Memory and mechanisms (pp. 5-47). Hillsdale, NJ: Erlbaum.

Watkins, L. R., Maier, S. F., \& Goehler, L. E. (1995). Immune activation: The role of proinflammatory cytokines in inflammation, illness responses, and pathological pain states. Pain, 63, 283-302.

WATKINS, L. R., \& MAYER, D. J. (1982). Organization of endogenous opiate and non-opiate pain control systems. Science, 216, 1185-1192.

Westbrook, R. F., \& Brookes, N. (1988). Potentiation and blocking of conditioned flavor and context aversions. Quarterly Journal of Experimental Psychology, 40B, 305-319.

Wiertelak, E. P., Smith, K. P., Furness, L., Mooney-Heiberger, K., Mayr, T., Maier, S. F., \& Watkins, L. R. (1994). Acute and conditioned hyperalgesic responses to illness. Pain, 56, 227-234.

WiLlner, J. A. (1978). Blocking of a taste aversion by prior pairings of exteroceptive stimuli with illness. Learning \& Motivation, 9, 125140

Yirmiya, R., Lieblich, I., Liebeskind, J. C., \& Garcia, J. (1988) Lithium chloride produces illness-induced analgesia. Bulletin of the Psychonomic Society, 26, 261-262.

(Manuscript received January 7, 1999; revision accepted for publication July 14, 1999.) 